Island Studies Journal, Vol. 3, No. 1, 2008, pp. 37-56

\title{
Studying Islands: On Whose Terms? \\ Some Epistemological and Methodological Challenges to the Pursuit of Island Studies
}

\author{
Godfrey Baldacchino \\ Island Studies Program \\ University of Prince Edward Island, Canada \\ gbaldacchino@upei.ca
}

\begin{abstract}
The pursuit of nissology, or island studies, calls for a re-centering of focus from mainland to island, away from the discourse of conquest of mainlanders, giving voice and platform for the expression of island narratives. Yet, studying islands 'on their own terms', in spite of its predilection for "authenticity", is fraught with epistemological and methodological difficulties. The insider/outsider distinction does not work all that well when it comes to islands, where hybridity is the norm. This paper seeks to extend this debate, grappling especially with the contributions of Grant McCall and Peter Hay to the sparse literature. Five dilemmas related to indigenous island geographies are presented and discussed, in a semiautobiographical style.
\end{abstract}

Keywords: island studies, outsiders, insiders, mainlanders, islanders, hybridity, re-centering

(C) 2008 Institute of Island Studies, University of Prince Edward Island, Canada

\section{Introduction}

Grant McCall (1994, 1996a, 1996b, 1996c), and following Christian Depraetere (1991), defined nissology as the study of islands on their own terms. The concluding phrase - "on their own terms" - suggests a process of empowerment, a reclaiming of island histories and cultures, particularly for those island people which have endured decades of colonialism. After all, "[C]ontinentals covet islands", McCall reminds us, while "[i]slanders themselves and their way of seeing things is not much appreciated" (McCall, 1996a: 1, 2). It may be, therefore, time for a change, also in the interests of political correctness. And yet, the opening segment of that same definition - "the study of islands" - marks an uncomfortable relationship, intimating that the process of inquiry may still be directed by outside forces, although presumably more well-meaning ones. 'Island studies' is explained not as a pursuit by islands/islanders, or with them, not even for them, but of them.

I allow myself to indulge in this topic also because of the fact that I am myself born an islander, trained on a mainland that is also an island (Malta), professionally engaged in 'island studies' while based on another island jurisdiction (Prince Edward Island), and someone who has spent a fair part of his adult life moving back and forth over illusory geographical boundaries and struggling to come to terms with competing identities. This paper will 


\section{G. Baldacchino}

hopefully help to refine the current state of 'island studies', while energizing and provoking a now overdue discussion about its foundational assumptions ${ }^{1}$.

\section{A Debilitating Discourse}

When excluding continents, islands cover some 7\% of the Earth's land surface, and are home to some $10 \%$ of the world's population. And while islands' contribution to endemic life and culture is recognized and celebrated, it is often outsiders - rather than insiders - who discover, investigate and proclaim such endemism and diversity to the rest of the world. The problematique of island inquiry is that there will always be epistemological and methodological challenges associated with studying islands, because we are grappling with the impact, conditioning and paradigmatic effects of the hybrid identity and 'location' of subjects (islanders, natives, settlers, tourists, second home owners), as well as those who would study them - who may be locals as well as outsiders (mainlanders, continental dwellers) - looking in.

Many island-related sites on the internet, and island-related literature, are run, or scripted, by non-islanders. The Islands Commission of the International Geographical Union, set up in 2007, has 12 members, including academics based in mainland France, mainland Germany, mainland Greece, mainland Netherlands, mainland Sweden and the continental USA (http://igu-islands.giee.ntnu.edu.tw/comm_memb.htm). Out of the 13 chapters of Hintjens \& Newitt (1992), all but three

“... are written by outsiders and inevitably they have something of the tone of outsiders telling the inhabitants of islands what they ought to be doing" (Newitt, 1992: 1).

The 'island studies reader' which I edited in 2007 has around half of its content penned by mainlanders - including Americans, Canadians, French, Swiss, Swedes ${ }^{2}$ - most of whom, as far as one can tell, do not reside on islands - in spite of a stated deliberate attempt by the editor to "provide platforms to other contributors" that may be more appropriately situated (Baldacchino, 2007a: 2). Embarrassingly, as one contributor (a Tongan) notes, there are indeed "... few indigenous islanders in the line-up of this book" (Helu Thaman, 2007: 519) ${ }^{3}$.

Like other contested, and contestable, border regions - the ocean depths, the high seas, outer space, and increasingly the Arctic - islands are treated as fair game for mainland subjugation and organization. The smaller, poorer or less populated the island gets, the more likely is it that its web, textual and literary content is dictated and penned by 'others'. All too often, we are faced with a situation where our subject matter - the island, the islander, the islanders becomes object matter: a "looked at" reference group; stages for the enactment of processes

\footnotetext{
${ }^{1}$ As John R Gillis rightly observes (pers. comm., November 2007): "island studies will not gain parity until there is an equally critical continental studies". Googling the phrases (within inverted commas) on March 8 , 2008, brings up 28,800 entries for 'island studies' and only 2,210 entries for 'continental studies'.

${ }^{2}$ Australians are here given the benefit of the doubt as to whether theirs is a mainland continent or a large island.

${ }^{3}$ But, as Stephen Royle cogently points out (pers. comm.., November 2007): "Thaman was right about the book. But ... if it was left up to islanders, (and good luck with defining who they are), would it have been written?"
} 
dictated from elsewhere; mere props of various 'deus ex machina', who would have been mainly explorers, missionaries and traders in the past, and replaced by other observers in more recent years. And, lest I be accused of attributing islanders to some pseudo-purist stock or pedigree, the 'looked at' reference group would easily include others - such as members of the diaspora, visitors, short term residents - who will disturb the distinction between local and global, and so make research into island life that much more challenging.

Already in the 1950s, when American anthropologist Robert Manners set off to conduct field research on the Caribbean island of St John, in the Virgin Islands, he soon realized that it was impossible to properly analyze the economy of that island by restricting the analysis to what was just happening on the island. He observed that "the traditional unit of research" - be it an individual, a household or a nation - was no longer co-terminous with "the unit of analysis" the island of St John proper (Manners, 1965: 182). The island and its people, whether they are physically present or absent, have already been effectively globalized. The disconnect between subject and physical geography is even more significant today (e.g. Foner, 2001). McCall's realization that emigration is such a central component of island life leads him to suggest islands as the original post-modern societies, sites and peoples that defy territoriality (McCall, 1996c: 8). Reductionism is appealing, and the myth of the 'pure island race' on which it is based is equally beguiling; but these representations hardly match the stark facts.

Following his first contact with the natives of Polynesia, anthropologist Raymond Firth had nonchalantly described them as "turbulent human material ... [to] be induced to submit to scientific study" (Firth, 1936: 1). This amounts to a removal of agency, cheating islanders of the possibility of defining themselves and of articulating their own concerns and interests. Political correctness may have brought to an end those explicit, at times even contradictory, references to "savages": be they noble, lethargic, lustful, uncultured or virtuous. Yet, islanders appear to continue to suffer as the passive and unwitting "objects of the gaze" of others unto this day. They persist as perennial targets of new 'civilizing missions': not only of academics and social researchers, but also of consultants, investors, journalists, film-makers, conservationists, novelists and tourists (e.g. Urry, 1990: 9). Island stuff is often either banalized and subsumed within a paradigm of structural deficiency (Hau'ofa, 1994); or else romanticized, rendered as coy subject matter; glimpsed fleetingly through rose-tinted glasses (Smawfield, 1993: 29):

"Might it not be possible, on this forbidden island, to avoid the cankers, minimize the nippings, and make the individual blooms more beautiful?" (Huxley, 1962: 128).

\section{Small and Tropical as Topical}

The reference to islands as 'small' reinforces this exercise in objectification. Why indeed should we continue to refer to small islands, or small island developing states (SIDS)? Why should we have an International Small Islands Studies Association (ISISA)? ${ }^{4}$ I much prefer using the word "smaller" instead of "small", resurrecting a usage preferred by Burton Benedict $(1966,1967)$ and Gerald Berreman $(1978)$, in order to draw attention to a tendency

\footnotetext{
${ }^{4}$ A point shared by Patrick Nunn, address to $7^{\text {th }}$ 'Islands of the World' Conference, Charlottetown, Prince Edward Island, June 2002.
} 


\section{G. Baldacchino}

in the literature - driven primarily by US-based political scientists - to equate large jurisdictions and territories as 'normal'. This, however, could not be further from the truth: out of 237 jurisdictions listed in the CIA World Factbook (CIA, 2006), only 23 have populations of over 50 million; while 158 have populations of less than 10 million (of which 41 with a population of up to 100,000 ). There are also some 21,000 'islands' in the world with a land area larger than $1 \mathrm{~km}^{2}$; but less than 300 with a land area larger than $1,000 \mathrm{~km}^{2}$ : this latter batch of 'islands' includes Eurasia, America, Africa and Australia (Dahl \& Depraetere, 2007: 67). Clearly, the so-called 'small state' or 'small island' - whether in land area or resident population - is the typical size. In contrast, the large is the quirk and anomaly.

The same can be said of the 'warm water' island. Perhaps one is here excused for assuming that the typical island is located in the tropics or sub-tropics, and is therefore warm, and its waters are tempting to swim in. Many cold water islands may be sparsely or unpopulated, but this does not render them invisible or devoid of life. Meanwhile, the marketing juggernaut of the tourism industry - itself built on powerful island tropes - ensures that the 'island equals warm' misperception remains commonplace (e.g. Baldacchino, 2006a). Moreover, if it is in the interest of governments to promote tourism to their island or archipelago, then we should also keep in mind that most of the four dozen or so sovereign countries of the world that are exclusively island or archipelagic states are located in the tropical or sub-tropical zones. Nevertheless, the physical evidence is skewed in the other direction. If one takes islands to be pieces of land permanently surrounded by water with a land area of at least $0.1 \mathrm{~km}^{2}$, then the distribution of islands according to latitude shows that most of them are located in the temperate and sub-arctic zones of the northern hemisphere, not in the tropics (Baldacchino, 2006b). The highest island density occurs between latitude $50^{\circ} \mathrm{N}$ and $80^{\circ} \mathrm{N}$ (precisely where there is the least amount of ocean), and a sharp peak within that band occurs between $58^{\circ} \mathrm{N}$ and $66^{\circ} \mathrm{N}$ (Dahl \& Depraetere, 2007: 77, Map 5).

The fact remains that the metaphoric deployment of 'island', with the associated attributes of small physical size and warm water, is possibly the central gripping metaphor within Western discourse (Hay, 2006: 26, emphasis in original). "The essence of the deserted island", Gilles Deleuze (2004: 12) argues, "is imaginary and not actual, mythological and not geographical". Yi-Fu Tuan (1990: 247) claims that four natural environments have figured prominently in humanity's (including non-Western) enduring and endearing dreams of the ideal world. They are: the forest, the shore, the valley and the island. Combinations of these - such as the island shore - become even more powerful symbolic imaginaries and reference points. Thus, the main stage for the blockbuster TV serial Lost is the shore of an unknown island on which passengers are stranded following an air crash $^{5}$. A recent full-page advert lists "Visit an Uninhabited Island" as one of twenty-one "[T]hings to do while you're alive".

\section{Making Sense}

How do islanders 'make sense' and derive meaning out of being at the receiving end of a powerful cultural, financial and technological regime (which we could refer to as deep globalization) that they cannot control, and which chooses to type and cast them in very

\footnotetext{
${ }^{5}$ Visit fan site at: http://www.lost-tv.com/.

${ }^{6}$ Life Takes Visa. (c) 2007 Visa U.S.A. Inc.
} 
specific ways, all reminiscent of smug, taxonomic subordination? As Stratford (2003: 495) reminds us:

"Islands $\ldots$ absolute entities ... territories, territorial; relational spaces - archipelagos, (inter)dependent, identifiable; relative spaces - bounded but porous; isolated, connected, colonized, postcolonial; redolent of the performative imaginary; vulnerable to linguistic, cultural, environmental change; robust and able to absorb and modify; ... utopian and dystopian, tourist meccas, ecological refugia..." (Stratford, 2003: 495).

There are various theoretical founts of inspiration that can provide answers to this question. Amongst these is the structural functionalist approach, as pioneered by Robert Merton (1968), which would classify their responses to this onslaught as likely to deal with choosing or not choosing to subscribe to the goals of those in power, and/or to subscribe to the methods seen as necessary to achieve those same goals. The conformists would uphold both goals and means, manifesting loyalty and pursuing similar material and status goods as their erstwhile imperial/continental masters - hence the "bicycle societies with Cadillac tastes" of the Caribbean ${ }^{7}$; the rebellious would discard both, and seek an overthrow of the status quo, or else would follow an alternative conceptualization of development (as may be the case of contemporary Cuba or the Samoan way of life). The ritualists would go through the motions of conformity but meaninglessly so, in a hollow and empty manner; while the retreatists would have nothing to do with the process of globalization and seek to disengage, as with McCall's (idyllic?) description of the subsistence economy on Kiribati (1996c: 6). The pesky innovators, finally, would seek to tweak the process, often intra-preneurially.

Alternative social theories grounded in Marxist thought, neo-colonialism and political economy perspectives tend to present islanders as individuals who are seen to respond positively but strategically in their actions to both proffered goals and means, while however questioning the legitimacy of the process, sensing that they operate from the periphery, and so at the receiving end of a fundamental, structural, power-unequal relationship (e.g. Lewis, 1976; Knights \& Willmott, 1989). They would thus exercise 'agency-in-context', compliance rather than commitment, identifying that it is coercive power, and not consensual authority, which is dictating how they should behave. This is also a fair analysis of typical islander behaviour in relation to tourists, where a hospitable and "welcoming society" (e.g. Husbands, 1983 ) is a lingering myth, but which even most islanders acknowledge as quite essential for the industry to exist.

A different, more complex, rendition of power is afforded by Foucault (1980: 39): here, power is understood as "capillary", disaggregated; this implies that there is no such thing as absolute power or absolute powerlessness; that power is better understood as embedded in regimes and routines, rather than possessed by individuals; and that power is best analyzed at its extremities, presumably where the paradigm is weakest. Islands, marginal by geography, many with a deep and long colonial infiltration, appear as ideal candidates for such an exercise. The celebration of locality in whichever shape or form, included the fabrication of a sense of nation, becomes a viable strategy for subverting the narratives and representations

\footnotetext{
${ }^{7}$ A soundbite attributed to a former First Minister of Montserrat. Quoted in Thorndike (1985: 8).
} 


\section{G. Baldacchino}

promulgated and imposed by external dominant powers and cultures ... even if hybridity is the outcome (Bhabha, 1995).

\section{Fleshing Out the Theories}

How are these theoretical observations fleshed out in practice in island life? How do islanders confront island texts so often crafted by non-islanders, where they become (with apologies to Jonathan Swift) stereotypical Lilliputians who only exist through the eyes, and texts, of an equally stereotypical Gulliver, and whose interest in island matters is fleeting and superficial (e.g. Baldacchino, 2004: 278)? Of course, most islanders will not even bother with the industry of their representation, perhaps feeling bemused and perplexed with how they continue to survive while continental scholarship has condemned them because of, first, 'the death of race' (e.g. Edmond, 2007), then 'non-viability' (e.g. Plischke, 1977), and later still 'chronic vulnerability' (e.g. Briguglio, 1995). Some islanders may be just as confused by how they are seen and objectified as 'paradises' by mainlanders, while they may struggle at home against un-/under-employment, aid dependency, loss of talent, waste mountains, eutrophied coasts and lagoons, sewage overflows, drug running, money laundering, HIV/AIDS, soil erosion, potable water shortage, depopulation or overpopulation. Others will accept the obsession to claim, objectify and render into beguiling metaphor as a necessary mythology to be endured, even refreshed and encouraged - perpetrated by their very own local branding organizations - since it bolsters the charm and mystique of their tourism industry, which may be their key foreign exchange generator. Moreover, 'living the lie' has its own rewards since it numbs and distances islanders from facing their own demons. Some other islanders will protest, resist and seek distinctiveness, overtly or covertly, laying claims to an exceptional, indigenously rooted counter-identity, positioning islands as bastions of biological and cultural diversity in contrast to the creeping sameness resulting from globalization. Some others will be confused by such statements about bio-diversity and endemism that are meant to redefine the net worth of what - to islanders - may be well-known, common, trite, local species of fish, flowers, trees, animals, insects, as well as land and seascapes and cultural traits (e.g. Clark, 2004). Yet another category of islanders would develop and hone those skills that allow them to engage mainlanders, manipulating their resources, humouring their objectives, fanning their fantasies, managing the very figurations of islands and island life that seek to type them, often surviving comfortably as glocal citizens in a split, schizoid world with (at least) two parallel sets of values, languages and practices ${ }^{8}$. And there will always remain those who have no qualms with bursting the metaphor's bubble and pointing out, by their actions, the sheer disjuncture between western/continental ideas and island life. Here, the mainlanders who wish to "do development" are not amused. The exasperated actions of (the revealingly named) Dolittle, an Australian "overseas expert", are a case in point: he is hired to "look into the feasibility of making the islanders of Tiko work on weekdays" but despairs after speaking with a VIP who fritters away the office hours, playing cards with his secretary (Hau'ofa, 1983). Finally, island life cannot be taken for granted: many islands have been totally depopulated, and others in the near future will suffer a similar fate, also as a function of sea level rise.

\footnotetext{
${ }^{8}$ As in the pursuit of both trading and piracy, as Jeremy Boissevain (pers. comm., January 2008) reminds me.
} 
One wonders whether, or to what extent, such a parody is true and whether it even remotely captures the basic contradiction of 'doing' development top-down. And yet, even if it did, it would be naïve to expect any islander to make a clean breast of it, and especially in writing. However, it should not surprise us that the formal disclosure of "the small conflicts and petty rivalries of parish pump politics in goldfish bowl societies" (Lillis, 1993: 6) is usually a task undertaken by non-islanders, who are in a sense 'non-participant' observers, unlike the socially embedded locals, and who can afford to make such revelations because they are not dependent on information management to survive, operate and flex their social power. Should we be surprised that some of the most insightful, and perhaps disturbing, written commentaries about social network practices - and their links to political party activism - in my home island country of Malta, have been developed by foreigners, especially European anthropologists (e.g. Boissevain, 1974; Mitchell, 2002), even if in somewhat too stylized a fashion? ${ }^{9}$

Outsiders, then, spared from being party to the divisions and personal animosities of their looked-at sub-set, could provide valid and insightful commentaries on island life. But this is not to say that (Maltese or any other) islanders are oblivious to the implications of their clannishness - hardly! Islanders, growing up in "a straitjacket of community surveillance" (Weale, 1992: 9), know the value of networks, and of the value of information about networks ${ }^{10}$. This is precisely why they do not readily disclose such information; and if/when they do, they do so orally/aurally, in the relative protection afforded by their own language or dialect, and with a view to score points, while carefully not revealing their vital sources. Idioms from small islands are replete with advice about how absolutely vital it is to protect one's sources of information ${ }^{11}$. External observers are not privy to such intricate social webbing, and are therefore not constrained by them. They may therefore find the motivation, space and audience for their comments, arrogant and mythologized though they might be. Meanwhile, island(er) agency is demonstrated via strategic inaction: a culture of silence and baited breath. This may explain why Maltese students ask so few questions (Boissevain, 1990 [1969]). As Prince Edward Island historian Edward MacDonald puts it: "The clenched fist cannot be shaken" (quoted in Weale, 2002). Islanders are:

"[A] very careful people, much given to evasion and slyness. The fear of giving or receiving offence fosters tentativeness. Forthrightness of speech and boldness of action become all but impossible" (Weale, 2002).

\section{Five Dilemmas}

\footnotetext{
${ }^{9}$ This is not to dismiss that Maltese scholars have made valid contributions - hopefully, myself included!

${ }^{10}$ A network is an ego-centric social matrix (Boissevain, 1968: 546). Different territories have their own name for it: lines in Guyana, bobol in Dominica, wantok in the Solomons ... (Baldacchino, 1997: 81).

${ }^{11}$ I used well-worn proverbs used in both Malta and Barbados (and elsewhere) to investigate the operation of small

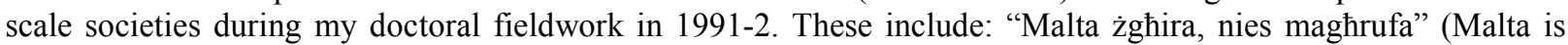
small; its people are well known); "Mhux kemm taf ighodd, imma lil min taf" (It is not what you know, but who you know, which matters); "Kelma bejn tnejn, bejn tlieta mnejn sa fejn?" (A word between two persons should not become a word between three); and from Barbados: "Bush has ears, Wall has eyes"; "Behind every bush there is a Man" and "If you play with the puppy, the puppy will lick your mouth" (The last of these means that familiarity breeds contempt). See (Baldacchino, 1997: 41- 44).
} 


\section{G. Baldacchino}

The richness of literary and cultural islanding could be so obtrusive and pervasive that it could actually threaten and dismiss the physicality of islands as 'real lived-in places'. Hay (2006: 30) argues emphatically:

"So powerful is the metaphorical idea of the island that it can be deployed in the absence of even the slightest reference to the reality of islands. Those who live real lives on islands are entitled to resent this."

One could say that the epitome of the objectification of islands would be reached when the island metaphor thrives on its own, as a simulacrum, without any trace of its physical referent. That would once again render islands as victims, this time of hyper-reality, a form of postmodern 'reality by proxy'. Bill Holm (2000: 59-82) tells us that his piano is an island. The first set of papers in Skinner \& Hills (2006), in a section titled 'Conceiving Islands', is “... not about islands at all but about metaphors of islandness" (Lowenthal, 2006: 259).

And so, ironically enough, while the island figures so prominently in the human psyche, and lurches from utopia to dystopia, from precise reference to banality, from a convenient (often exotic) laboratory setting, to a platform for the observation of the dynamics of "amplification by compression" (e.g. Percy et al., 2007: 193), the islanders themselves are hard put to reflect openly on their predicament.

Do islanders react at all to the slippage in the analysis of their condition, where they continue to be ritually "aesthesicized, sanitized and anaesthetized" (Connell, 2003a: 568)? How do they perform as conscripted actors in a play about 'island life' that they rarely control? How do they behave when they are targets of an incessant regimen of construction, which would have them behave this way and that, in ways that fulfil the desires and dreams of all, for all seasons and for all tastes? Resentment, as Hay put it, is only one of a variety of ways in which islanders can 'react'.

There are various other ways. Islanders can and do (re)act to the interest - including their own - in the study of islands. In so doing, at least five dilemmas - and there may very well be others - come to mind and are discussed and problematized below: (1) that of the pursuit of extended colonial relationships by various island jurisdictions; (2) that of revealing - and so risk offending - island sensitivities, and the possible consequences of such disclosure; (3) the choice of language and communication format; (4) the exploitation of one's own island predicament as an unfortunate victim of environmental disaster; and (5) the realization that, deep down, we are probably all guilty of imperialism.

Each of these issues will be reviewed in turn below. Readers may note that some, if not all, of the observations which follow can be widespread or even universal, and need not be restricted or exclusive to islands; although they may prove to be more prominent or significant in an island context.

The first dilemma is that the enduring 'cultures of loyalty' (Dodds, 2007) of many island peoples to metropolitan powers and former imperial heartlands sit uneasily with the mantra of sovereignty as an intrinsically laudable and almost historically unavailable, evolutionary 
route. Thus, "postcolonialism research ... still finds it easier to pick on, and grapple with, Algeria rather than Mayotte, India rather than Bermuda, and Indonesia rather than Aruba" (Baldacchino, 2007b). The expectation that islanders show abject resentment to the colonial experience may often itself be the outcome of an unconscious, mainlander dogmatism. Postcolonial theorization and international relations are both slowly coming round to acknowledge that there is no obligation for all colonized territories to secure full independence, certainly in the short to medium term (e.g. Edmond \& Smith, 2003: 5-6; Baldacchino \& Milne, forthcoming). Especially for small islands, there is quite a compelling case to be made today for autonomy without sovereignty. After all:

"In an uncertain world, a substantial degree of autonomy, where culture and identity are respected and protected, reasonable access to employment and services exists, and security is guaranteed, has weakened the strength of the claim to independence." (Connell, 2003b: 141).

What about those who choose nevertheless to articulate the not-so-paradisiacal intricacies of island life? Where islanders script contemporary island life, they may still go for relatively 'soft' thematics - like the power of gossip, the resilience of family, the lure of migration which are not likely to meet the disapproval or wrath of fellow islanders. Many commentators on sensitive island affairs remain foreigners. But here emerges the second dilemma. Of those islanders who do comment on sensitive island affairs amongst this grouping, many would be commenting from a safe distance, as emigrants, as members of island diasporas, as transnationals relatively disengaged from the society they are analyzing, and exposing. Or, for the others who are brave (or foolish?) enough to attempt revelations from within, they may find that they fall victim to the 'crab in the barrel' syndrome (Baldacchino, 1997: 118): become effectively blacklisted, humoured, belittled, cut down to size or somehow marginalized in their own land - in which case, physical or psychological ex-i(s)le may again kick in. To what extent can the 'island as prison' afford its inmates to comment about internal happenings? As Samoan novelist Sia Figuel (1996: 131) wryly observes:

"I come from a very small island - it's closed in - in a sense that everyone knows everyone ... it can be very confining".

Note that the above is not written in Samoan. A third dilemma that presents itself in the practice of nissology/island studies deals with both the language and form of communication. In societies where indigenous speech may never have existed - such as in territories which had been uninhabited before the European Age of Discovery - or where indigenous speech (and its speakers) has been lost and replaced by metropolitan languages, the dilemma is nonexistent: the language of resistance and the language of oppression are but one and the same. Thus, in the imperially manufactured societies of the contemporary Caribbean, as Naipaul (1973: 275) describes them, creole is often celebrated as a subaltern medium, while at the same time it can be followed, with differential levels of difficulty, by speakers of the regular language (Bongie, 1998) ${ }^{12}$. It is perhaps therefore not surprising that the French and English

\footnotetext{
${ }^{12}$ However, is not creole, after all, an islanders' own language, in its hybridity? There are power relations at work in defining what is a language and what is not.
} 


\section{G. Baldacchino}

Caribbean are amongst the best known producers of island scripts; island stories on their own terms.

Where multiple languages exist, as in the Pacific and Indian Oceans, or the Mediterranean basin, a stark dilemma emerges. Using the vernacular appears more appropriate as a medium for local commentary - historically, such languages were used, and seen, as natural tools and drivers of resistance - but this option would automatically limit readership and distribution to the speakers or readers of that language. Unless translated, or somehow reported or paraphrased, into a language of international currency, external readers would remain largely oblivious to such texts and their messages. Even the very form of a text - such as a novel, a poem, or a play - betrays an embedded and often uncritical relationship to western technologies of representation (e.g. Jameson, 1986: 69). Whereas, for a Faroese or Greenlander to write a thesis in Danish, for a New Caledonian or Seychellois to write a poem in French, for an Aruban or a Sint Maartiner to compose the lyrics of a song in Dutch, or for a Samoan or Ni-Vanuatu to write a novel in English, opens up much larger potential markets, many more publishing options, and possible a much wider, even international, acclaim. The choice of language is an issue that cannot be avoided for such island authors; some would seek to write the same, or different, texts in different languages, even if just to prove to themselves that they can articulate their ideas equally well to different linguistic audiences, and hopefully satisfy complimentary markets ${ }^{13}$.

There is also some attempt by islanders to generate regional and international interest in the condition of their islands, especially that of low lying island states at the risk of sea level rise. Yet, paradoxically, where are those who would love islands when they are called upon to take actions that mitigate global warming? Indeed, Farbotko (2005) has shown, in her gripping analysis of the representation of Tuvaluans in the Sydney Morning Herald, that these islanders are often portrayed in the metropolitan press as victims of tragic circumstances beyond their control, fitting easily into stereotypes of dehistoricized vulnerability and 'paradise in peril' which the rest of the world can watch - absolved of any responsibility - as they unfold, almost like a slow-motion movie, and presumably from a safe vantage point (e.g. DeLoughrey, 2007: 214). For those who want a closer experience, certain island jurisdictions - like Greenland, and the Maldives - have actually started marketing their tourist industry with a dark twist: appealing to those who wish to visit paradise "before it is too late" (Farbotko, 2005: 285). Herewith the fourth dilemma: it is quite disheartening and unsettling to discover that the interests of the first world in island life can continue to be held, even if tentatively, when islands and islanders are depicted as threatened exotic curiosa in the grand museum of civilization. Bikini, the Pacific atoll that gave its name to a sexy swim suit, is far better known internationally as a byword for erotic seduction than as a site of radioactive fallout and agonizing death (Gillis \& Lowenthal, 2007: iv). Some islanders may be silently thankful that even a perverse interest by the international community is better than no interest at all.

There is at least one other, fifth, dilemma: that relating to the absence of pure categories. Hay (2006: 30) insists that Nissology - (with a capital 'N') - the study of islands on their own terms - is "... for islands and for islanders in the times that are here and that are emerging." McCall (1996c: 9) twice exalts "We Islanders" as the experts, owners and stewards of the

${ }^{13}$ As I myself have done, having written books in either Maltese and English languages, and one in both. 
waters of the planet. But what/who exactly is, and isn't, an islander? We must confront island roots with island routes (after Clifford, 1997), recognize the almost inevitable urge or need of islanders to escape, to develop 'glocal' identities, to invest in connectivities, to search for a sufficiently removed perch from which to observe one's island and manage the pain, as a condition of island life. Thus, and by way of example, Albert Wendt, one of the most prolific and best known writers from Samoa, lived on another island archipelago (Aotearoa/New Zealand) for decades (Baldacchino, 2006c: 149; DeLoughrey, 2007: 198). Wayne Johnston, who is from and writes about Newfoundland, has lived in Toronto since 1989. Novelist Makeda Silvera was born in Jamaica and now lives in Canada (Silvera, 2002). Célestine Hituira Vaite, born and raised in Tahiti, now lives in Australia (Vaite, 2004) ... Are the members of island diasporas, or even those islanders who spend long periods 'away', disqualified from interpreting island lives? And conversely, by way of example, it is often mainlanders who have secondary homes on islands who are often much more enthusiastic and vociferous than those who were born and raised on islands in defending the 'island way of life', in valuing traditional dwellings, and resisting pressure to connect islands to mainlands via such 'fixed links' as bridges, tunnels and causeways (Baldacchino, 2007c).

Moreover, what exactly is an island? Without delving into the fine details of computer science (e.g. Mandelbrot, 1982; Royle, 2007), geographers remind us of the fractal nature of islands: with larger magnification, what may have been a small island off a mainland itself becomes 'the mainland' for even smaller islands (Dahl \& Depraetere, 2007: 64). Even Pete Hay's Tasmania (as a state within the Commonwealth of Australia) is actually an archipelago, recognized as having some 330 accompanying islands, some of which are inhabited, and some of which have their own notorious pasts. Various Tasmanian writers, look beyond their 'mainland': like Richard Flanagan - who comments about life on the penal colony of Sarah Island, off the main island of Tasmania proper, in Gould's Book of Fish (Flanagan, 2001); or Danielle Wood, whose protagonist in Alphabet of Light and Dark (Wood, 2003) returns to Bruny Island, another outlier. Does then this stance render these writers usurpers? Are they a lesser form of 'island scholar'? Are Sarah and Bruny Islands re-colonized by being scripted by 'mainland' Tasmanians? The inhabitants of even small islands are bound to have even smaller islands that attract their interest; and, in such a case, they are just as likely to behave as mainlanders, as rapacious Gullivers snooping in, objectifying their subject matter ${ }^{14}$. Ask the Gozitans about the Maltese ${ }^{15}$, les Rodriguais about les Mauritiens (e.g. Gardella, 1983), the Nevisians about the Kittitians; and the Tuvaluans about the (ethnically different) IKiribati. The islanders of Britain, Crete, Japan and Venice have all been colonizers at some stage (Warrington \& Milne, 2007). But it doesn't stop there: the pattern of uncritical representation can be reversed and the proverbial tables can be turned: the islanders have their own scripted versions of their respective mainlands and mainlanders: chaotic, fast, impersonal, dangerous, distant seats of government, hotbeds of crime and licentiousness, potential founts of much needed investment. The love/hate relationship between island(er)

\footnotetext{
${ }^{14}$ The largest island in such places as Shetland and Orkney is itself called 'Mainland'. I thank Stephen Royle for reminding me of this.

${ }^{15}$ The Maltese would not think twice to condemn even a good Gozitan to be burnt at the stake, and a wicked one

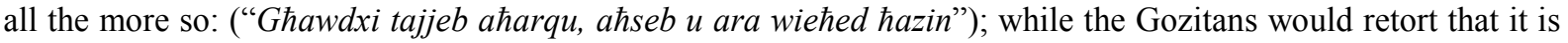
always better to hang a Maltese than a dog ("Ahjar tghallaq Malti milli tghallaq kelb"). I am grateful to Maria Grech, (Ta'Bejża) of Xewkija, Gozo, for this colourful information.
} 


\section{G. Baldacchino}

and mainland(er) is as real as the unavoidable bond between them. Turning the tables on the mainland for a change by scripting it - even as one is being scripted by it - sounds like a fine corrective to so much historical subordination. But, surely: two wrongs don't make a right. Moreover, no science has ever been constituted in such a way that the place of birth or residence of the researcher is relevant and even decisive for the constitution of a discipline ${ }^{16}$.

And so it appears that, thanks to the ironies of physical geographies, most of us are destined, or blest, with always having someone/something else to colonize. We may just have to live with that humbling remorse.

\section{Conclusion: Islands Fight Back?}

I will be the first to admit that a more systematic analysis of these five dilemmas is called for. ${ }^{17}$ But the basic thrust is that, for all their elusiveness and fuzziness, both external and internal understandings are necessary for a fuller, deeper understanding of island life.

To be sure, there is some attempt at reclaiming the island by islanders. Thus, as Konai Helu Thaman, Tongan national and senior academic at the University of the South Pacific, has commented (2007: 520, emphasis in original):

"In our region today, Pacific scholars and researchers are committed to telling their own stories, and preferably in their languages. They are now working on implementing the Declaration on Bioethics and Human Rights, adopted by the United Nations in October 2005, which respects the dignity and protects the integrity of researched individuals and communities. This could greatly impact on the types of research people are allowed to carry out in Pacific island communities, as well as on the processes and products of such research.

To this end, I would encourage the trend to devote more time towards researching WITH and FOR communities, rather than detached academic endeavour. The University of the South Pacific is at the forefront of advocating this approach, especially in relation to the types of research our staff are involved in, as well as the way that research is reported and disseminated".

The nissological project is one intended for indigenous geographies; and yet, for all its noble intentions, it remains problematic to operationalize, certainly where islands are concerned. Continental interest in island life - as in the observation of endemic species - will persevere. The tourist fascination with the island utopia remains critical to so many island economies, even if the enthrallment is with an island on the verge of submersion. The very act of commenting 'from outside' remains pertinent; since even islanders are obliged to resort to such a positioning in order to be able to disclose.

\footnotetext{
${ }^{16}$ I am grateful to Hernan Diaz (personal communication, November 2007) for this comment.

${ }^{17} \mathrm{I}$ am also aware that an alternative (and maximalist) approach to the mainland-island duality is to argue that we are all islanders; and that there are no such things as mainlands, only islands (see Depreatere, this volume).
} 
Moving away from an exclusive mainlander 'gaze', and the manner in which it stereotypically positions islanders in tightly predetermined modalities - as Gulliver/Lilliputians, Prospero/Caliban or Robinson Crusoe/Man Friday - is commendable. It is high time, argues McCall (1996a: 13), to present nissology/island studies as a "subaltern discourse" and for the island to "write back" (Garuba, 2001: 65). But: who is going to write, about what, and in what way? There may be no pure islanders ready and waiting to take over the task of (re)construction. McCall's plea is more of a desire for an alternative conceptualization of the world with a view to achieving a more sustainable relationship between humankind and nature, than of a valid field of study in its own right with its own principles, constructs and methodologies. His assumption that islanders make better custodians of their environment may also be premised on aspects of human-nature interactions on islands that no longer exist in the modern world, and - on the basis of archaeological evidence - may not even have ever existed in the pre-modern era (e.g. Fitzpatrick, 2007: 86). Indeed, today we refer to a particular example of non-sustainability - involving mounting human consumption, destruction and pollution to levels which threaten nature's generative capacity - as the "Easter Island syndrome" (e.g. Nagarajan, 2006).

One must therefore be vigilant as to how nissologists / 'island scholars' may be reinterpreting 'terms' for islands, but maintaining the same deep structure and its colonizing disposition: while side-lining the narrative away from the perspective of the 'explorer-discoverercolonist', it may be taken over by the perspective of the 'custodian-steward-environmentalist'. In this shift, the island narrative is still not enough a narrative by, for or with, islanders but remains one of and about them. It persists doggedly as a hegemonic discourse of conquest. It is not so surprising that claims for reading islands on their own terms are driven by passionate mainlanders who often still come along with preconceived ideas about what islands should be, and how islanders should behave.

At the same time, one must be aware of how deep-rooted and stultifying the social consequences of islandness can be: we can perhaps safely call this feature insularity. The conservative nature of small societies, with their multiplex relationships, breeds a "crab in a barrel" syndrome that rewards egalitarianism and penalizes those who stand out, perhaps to pass critical commentary (Benedict, 1966; Sutton \& Payne, 1993; Lowenthal, 1987) - note that these three references are all to outsiders, looking in.

Island studies /nissology has been conceived as a platform for looking at island issues inductively and ex-centrically: privileging commentary from the inside out (rather than from the outside in). This positioning - equivalent to the islanders" "way of seeing things" according to McCall (1996a: 2) - is valuable, fresh and in contrast to so much received wisdom and historical narrative. Yet, in some respects, it is not necessarily any different from the script it is vying to replace. Its proponents, for all their virtuous intent - and I include myself amongst them - cannot escape the accusation of being, in their own way, colonial. These narrators are not necessarily avoiding a romanced essentialization of their research domain (in the guise of Negritude, 'The Pacific Way', enticing tourist brochures, pristine ecosystems, or unadulterated island people). Nor are they necessarily open to exciting new insights or interpretations as may emerge from inductive research. Moreover, so many of these indigenous narratives will remain unacknowledged, unarticulated, unwritten, or else 


\section{G. Baldacchino}

written only in languages, or expressed in voices, that very few of us would understand - and perhaps strategically and intentionally so.

Commentaries may be best judged by considering the positioning of their authors. Islanders may display considerable partiality and bias than a more distant and perhaps more objective outsider. They may denigrate and corral outsiders and their advice, and not always for justifiable reasons. There are also, within the 'islander' category, clear divisions in terms of gender, class, race and/or ethnicity that need to be acknowledged. And yet, so much more remains to be said by islanders about themselves. The "myth of continents" (Wigen \& Lewis, 1997) hangs like an ominous cloud over island studies. Nevertheless, and especially where contemporary political and social commentary is concerned, islanders - and some more than others - may prefer to keep quiet and act in less obvious and compromising ways, and not just because they may fear retaliation. Indeed, were 'outsiders' not involved in the (problematic) task of commenting on and about islands, most of us would be facing the dire prospects of an absent script. The inclusion of the 'islander-as-subject' / indigenous point of view cannot be ignored; but nor can it be construed as exclusive.

If island(er)s are hybrid, glocal, shifting, defiantly unstable, and inherently undefinable, how then do we address and temper the enthusiasm to preserve their essence, their sense of place, however flexible it may be? How can island studies manage this "nervous duality" (Baldacchino, 2005: 248): defending, even celebrating, an 'inside' that is resentful of what is felt to be an overbearing 'outside'; when the outside is essential for island(er) survival, its representation, its very identity? All forms of understandings are needed for a fuller, deeper appreciation of the island condition: surely, island studies will only be richer by nurturing these.

\section{Acknowledgements}

An earlier draft of this paper was presented at the $1^{\text {st }}$ International Conference of the Islands Commission of the International Geographical Union (IGU), held in Taipei, Taiwan, October 29-31, 2007. My sincere thanks to Jeremy Boissevain, Ron Crocombe, Hernan Diaz, Mark Anthony Falzon, Matt Funk, John R. Gillis, Laura Lee Howard, Jerome L. McElroy, Beate Ratter, Stephen A. Royle and Philip E. Steinberg for generous and critical comments. The usual disclaimers apply.

\section{References}

Baldacchino, G. (2007a) 'Introducing a World of Islands' in G. Baldacchino (ed.) A World of Islands: An Island Studies Reader, Charlottetown, Canada and Luqa, Malta, Institute of Island Studies and Agenda, pp. 1-29.

Baldacchino, G. (2007b) “"Upside Down Decolonization”: The Strategic Permanence of Colonialism in Sub-National Island Jurisdictions', paper presented at Conference on Postcolonial Islands, Belfast, Northern Ireland, Queen's University, September. 
Baldacchino, G. (ed.) (2007c) Bridging Islands: The Impact of Fixed Links, Charlottetown, Canada, Acorn Press.

Baldacchino, G. (2006a) Extreme Tourism: Lessons from the World's Cold Water Islands, Oxford, Elsevier.

Baldacchino, G. (2006b) 'Editorial Introduction' in Extreme Tourism: Lessons from the World's Cold Water Islands, Oxford, Elsevier, pp. 3-14.

Baldacchino, G. (2006c) 'The Brain Rotation and Brain Diffusion Strategies of Small Islanders: Considering 'Movement' in lieu of 'Place', Globalisation, Societies and Education, Vol. 4, No. 1, pp. 143-154.

Baldacchino, G. (2005) 'Islands: Objects of Representation', Geografiska Annaler B, Vol. 87, No. 4. pp. 247-251.

Baldacchino, G. (2004) 'The Coming of Age of Island Studies', Tijdschrift voor Economische en Sociale Geografie, Vol. 95, No. 3, pp. 272-283.

Baldacchino, G. (1997) Global Tourism and Informal Labour Relations: The Small Scale Syndrome at Work, London, Mansell.

Baldacchino, G. \& Milne, D. (eds.) (2008) The Case for Non-Sovereignty: Lessons from SubNational Island Jurisdictions, London, Routledge, forthcoming.

Benedict, B. (ed.) (1967) Problems of Smaller Territories, London, Athlone Press for the Institute of Commonwealth Studies.

Benedict, B. (1966) 'Sociological Characteristics of Smaller Territories and their Implications for Economic Development' in M. Banton (ed.), The Social Anthropology of Complex Societies, London, Tavistock, pp. 23-34.

Berreman, G. (1978) 'Scale and Social Relations', Current Anthropology, Vol. 19, No. 2, pp. 225-245.

Bhabha, H. (1995) Location of Culture, London, Routledge.

Boissevain, J. (1990) 'Why do the Maltese ask so few Questions?', Education, Journal of the Faculty of Education, University of Malta, Vol. 3, No. 4, pp. 16-18. Previously published in Ferment, Malta, Vol. 7, 1969, pp. 18-22.

Boissevain, J. (1974) Friends of Friends: Networks, Manipulations and Coalitions, Oxford, Blackwell.

Boissevain, J. (1968) 'The Place of Non-groups in the Social Sciences', Man, Vol. 3, No. 4, pp. 542-556. 


\section{G. Baldacchino}

Bongie, C. (1998) Islands and Exiles: The Creole Identities of Post/Colonial Literature, Stanford CA, Stanford University Press.

Briguglio, L. (1995) 'Small Island Developing States and their Vulnerabilities', World Development, Vol. 23, No. 9, pp. 1615-1632.

CIA (2006) CIA World FactBook, Washington DC, Central Intelligence Agency, www.cia.gov/cia/publications/factbook/

Clark, E. (2004) 'The Ballad Dance of the Faroese: Island Biocultural Geography in an Age of Globalization', Tijdschrift voor Economische en Sociale Geografie, Vol. 95, No. 3, pp. 284-297.

Clifford, J. (1997) Routes: Travel and Translation in the Late Twentieth Century, Cambridge MA, Harvard University Press.

Connell, J. (2003a) 'Island Dreaming: The Contemplation of Polynesian Paradise', Journal of Historical Geography, Vol. 39, No. 4, pp. 554-581.

Connell, J. (2003b) 'New Caledonia: An Infinite Pause in Decolonization?', The Round Table: Commonwealth Journal of International Affairs, Vol. 92, No. 368, pp. 125-143.

Dahl, A.L. \& Depraetere, C. (2007) 'Island Locations and Classifications' in G. Baldacchino (ed.) A World of Islands: An Island Studies Reader, Canada and Malta, Institute of Island Studies and Agenda, pp. 57-106.

Deleuze, G. (2004) Desert Islands and Other Texts: 1953-1974, edited by D. Lapoujade, Paris, Semiotext(e).

Depraetere, C. (1991) 'NISSOLOG: Base des Données des Îles de plus de $100 \mathrm{~km}^{2}$ ', presentation at $17^{\text {th }}$ Pacific Science Congress, Honolulu HI, MSDOS computer program and unpublished manuscript, Centre de Montpellier, France, Editions de l'OSTROM.

DeLoughrey, E.M. (2007) Routes and Roots: Navigating Caribbean and Pacific Island Literatures, Honolulu HI, University of Hawaii Press.

Dodds, K. (2007) 'Cultures of Loyalty', paper presented at conference on Postcolonial Islands, Belfast, Northern Ireland, Queens University, September.

Edmond, R. (2007) 'Dying Races', paper presented at conference on Postcolonial Islands, Belfast, Northern Ireland, Queens University, September.

Edmond, R. \& Smith, V. (eds.) (2003) Islands in History and Representation, London, Routledge. 
Farbotko, C. (2005) 'Tuvalu and Climate Change: Constructions of Environmental Displacement in the Sydney Morning Herald', Geografiska Annaler, Vol. 87B, No. 4, pp. 279-294.

Figiel, S. (1996) Where We Once Belonged, Auckland, New Zealand, Pasifika Press.

Firth, R. (1936/1983) We, The Tikopia: A Sociological Study of Kinship in Primitive Polynesia. Stanford CA, Stanford University Press.

Fitzpatrick, S. (2007) 'Archaeology's Contribution to Island Studies', Island Studies Journal, Vol. 2, No. 1, 2007, pp. 77-100.

Flanagan, R. (2001) Gould's Book of Fish: A Novel in Twelve Fish, New York, Grove Press.

Foner, N. (ed.) (2001) Islands in the City: West Indian Migration to New York, Berkeley CA, University of California Press.

Foucault, M. (1980) Power/Knowledge: Selected Interviews and Other Writings: 1972-1977, edited by Colin Gordon, New York, Pantheon.

Gardella, A.M. (1983) 'Creoles, Montagnards, Rodriguais: Stalking Ethnicity in the Indian Ocean', paper presented at conference on the history of ethnic awareness in Southern Africa, Charlottesville, 7-10 April.

Garuba, H. (2001) 'The Island Writes Back: Discourse/Power and Marginality in Wole Soyinka's The Swamp Dwellers, Derek Walcott's The Sea at Dauphin, and Athol Fugard's The Island', Research in African Literatures, Vol. 32, No. 4, pp. 61-76.

Gillis, J.R. \& Lowenthal, D. (2007) Editorial Introduction', Geographical Review, Vol. 97, No. 2, pp. iii-vi.

Hay, P. (2006) 'A Phenomenology of Islands', Island Studies Journal, Vol. 1, No. 1, pp. 1942, http://www.islandstudies.ca/journal/ISJ-1-1-2006-Hay-pp19-42.pdf.

Hau'ofa, E. (1994) 'Our Sea of Islands', The Contemporary Pacific, Vol. 6, No. 1, pp. 148161.

Hau'ofa, E. (1983) Tales of the Tikongs, Auckland, Longman Paul.

Helu Thaman, K. (2007) 'Towards Different Island Research' in G. Baldacchino (ed.) $A$ World of Islands: An Island Studies Reader, Canada and Malta, Institute of Island Studies and Agenda, pp. 519-520.

Holm, B. (2000) Eccentric Islands, Travels Real and Imaginary, Minneapolis MN, Milkweed Books. 


\section{G. Baldacchino}

Husbands, W.C. (1983) 'The Genesis of Tourism in Barbados: Further Notes on the Welcoming Society', Caribbean Geography, Vol. 1, No. 1, pp. 107-120.

Huxley, A. (1962) Island: A Novel, Toronto, Clarke, Irwin \& Co.

Jameson, F. (1986) 'Third World Literature in the Era of Multinational Capitalism', Social Text, Vol. 15, No. 1, pp. 65-88.

Knights, D. \& Willmott, H. (eds.) Labour Process Theory, London, Macmillan.

Lewis, V.A. (ed.) (1976) Size, Self-Determination and International Relations: The Caribbean, Kingston, Jamaica, Institute of Social and Economic Research, University of the West Indies.

Lillis, K.M. (1993) 'Introduction: Key Issues and Perspectives' in K.M. Lillis (ed.) Policy, Planning and Management of Education in Small States, Paris, UNESCO, International Institute for Educational Planning, pp. 1-21.

Lowenthal, D. (2006) 'Book Review' of Skinner and Hills, op. cit., Island Studies Journal, Vol. 1, No. 2, pp. 259-261.

Lowenthal, D. (1987) 'Social Features' in C. Clarke \& A. Payne (eds.) Politics, Security and Development in Small States, London, Allen \& Unwin, pp. 26-49.

Mandelbrot, B. (1982) The Fractal Geometry of Nature, New York, W. H. Freeman \& Co.

Manners, R.A. (1965). "Remittances and the Unit of Analysis in Anthropological Research", Southwestern Journal of Anthropology, Vol. 21, No. 3, pp. 179-195.

McCall, G. (1994) 'Nissology: The Study of Islands', Journal of the Pacific Society, Vol. 17, Nos. 2-3, pp. 1-14.

McCall, G. (1996a) 'Nissology: A Debate and Discourse from Below', 19pp, www.southpacific.arts.unsw.edu.au/resourcenissology.htm.

McCall, G. (1996b) 'Clearing Confusion in a Disembedded World: The Case for Nissology', Geographische Zeitschrift, Vol. 84, No. 2, pp. 74-85.

McCall, G. (1996c) 'How to tell the Private Sector when you see it: Nissological Notes from the Pacific Islands', paper presented at conference on economic globalization and regional integration of small countries, Nicosia, Cyprus, September.

Merton, R.K. (1968) Social Theory and Social Structure, 2nd edition, New York, The Free Press. 
Mitchell, J.P. (2002) Ambivalent Europeans: Ritual, Memory and the Public Sphere in Malta, London, Routledge.

Nagarajan, P. (2006) 'Collapse of Easter Island: Lessons for Sustainability of Small Islands', Journal of Developing Societies, Vol. 23, No. 3, pp. 287-301.

Naipaul, V.J. (1973) The Overcrowded Barracoon, New York, Alfred A. Knopf.

Newitt, M.D.D. (1992) 'Introduction' in H.M. Hintjens \& M.D.D. Newitt (eds.) The Political Economy of Small Tropical Islands, Exeter, University of Exeter Press, pp. 1-17.

Percy, D., Blackmore S. \& Cronk, Q.C.B. (2007) 'Island Flora' in G. Baldacchino (ed.) A World of Islands: An Island Studies Reader, Canada and Malta, Institute of Island Studies and Agenda Academic, pp. 175-198.

Plischke, E. (1977) Microstates in World Affairs, Washington DC, American Enterprise Institute for Public Policy Research.

Royle, S.A. (2007) 'Definitions and Typologies' in G. Baldacchino (ed.) A World of Islands: An Island Studies Reader, Canada and Malta, Institute of Island Studies and Agenda, pp. 3356.

Silvera, M. (2002) The Heart does not Bend, Toronto, Vintage Canada.

Skinner, J. and Hills, M. (eds.) (2006) Managing Island Life: Social, Economic and Political Dimensions of Formality and Informality in 'Island' Communities, Dundee, Scotland, University of Abertay Press.

Smawfield, D. (1993) 'Notions of Smallness: What are they and what are their Implications?' in K.M. Lillis (ed.) Policy, Planning and Management of Education in Small States, Paris, France, UNESCO, International Institute for Educational Planning, pp. 25-47.

Stratford, E. (2003) 'Editorial: Flows and Boundaries: Small Island Discourses and the Challenge of Sustainability, Community and Local Environments', Local Environment, Vol. 8, No. 5, pp. 495-499.

Sutton, P. \& Payne, A. (1993) 'Lilliput under Threat: The Security Problems of Small Island and Enclave Developing States’, Political Studies, Vol. 41, No. 4, pp. 579-593.

Thorndike, T. (1985) Grenada: Politics, Economy and Society, London, Frances Pinter.

Tuan, Yi-Fu (1990) Topophilia: A Study of Environmental Perception, Attitudes and Values, $2^{\text {nd }}$ edition, New York, Columbia University Press.

Urry, J. (1990) The Tourist Gaze: Leisure and Travel in Contemporary Societies, London, Sage. 


\section{G. Baldacchino}

Vaite, C. (2004) Frangipani: A Novel, New York, Little, Brown and Company.

Warrington, E. \& Milne, D. (2007) 'Island Governance' in G. Baldacchino (ed.) A World of Islands: An Island Studies Reader, Canada and Malta, Institute of Island Studies and Agenda, pp. 379-428.

Weale, D. (2002) 'Here and Away', paper presented at $7^{\text {th }}$ Islands of the World Conference, International Small Islands Studies Association, Charlottetown, Canada, Institute of Island Studies.

Weale, D. (1992) Them Times, Charlottetown, Canada, Island Studies Press.

Wigen, M.W. \& Wigen, K.E. (1997) The Myth of Continents: A Critique of Metageography, Berkeley CA, University of California Press.

Wood, D. (2003) The Alphabet of Light and Dark, Sydney, Allen \& Unwin. 